\title{
Penambahan tepung daun pegagan (Centella asiatika) terhadap performa produksi puyuh
}

\author{
Yuli Arif Tribudi ${ }^{1)}$ dan Arina Nurfianti ${ }^{2)}$
}

1) Program Studi Peternakan Fakultas Pertanian Universitas Tanjungpura

2) Program Studi Keperawatan Fakultas Kedokteran Universitas Tanjungpura

J1. Prof dr. H. hadari Nawawi Pontianak Kalimantan Barat 78124

Correspondence author : yuliariftribudi@gmail.com

\begin{abstract}
The study of this research was to evaluate the effect of pegagan (Centella asiatica) on quail production performance. The materials used in this study were 200 quail phase layer Coturnix-coturnix japonica strain. The method used was experimental design with completely randomized design (CRD) with 4 treatments and 5 replications. The treatments in this study were the feed control without the addition of pegagan meal $\left(\mathrm{P}_{0}\right)$; $0.5 \%\left(\mathrm{P}_{1}\right) ; 1 \%\left(\mathrm{P}_{2}\right)$ and $1.5 \%$ pegagan meal $\left(\mathrm{P}_{3}\right)$. The variables observed were feed intake (g/bird /day); Hen Day Production (\%); feed conversion and egg weight (g/bird/day). The results of this research showed that pegagan meal not effect significantly $(\mathrm{P}>0.01)$ on feed intake (g/bird/day), Hen day Production (\%); feed conversion and egg wight (g/bird/day) in quail production performance.it can be conclued that Feed intake, Hen day Production, feed conversion and egg wight was best on $\mathrm{P}_{3} .1,5 \%$ pegagan meal in the feed were advised
\end{abstract}

Keywords : feed aditive, pegagan, feed, quail, performance

\section{PENDAHULUAN}

Puyuh merupakan unggas dual porpose, yakni hewan dengan manfaat ganda yakni sebagai ternak penghasil daging dan telur sehingga puyuh dapat dijadikan sebagai sumber pemenuhan protein hewani. Populasi puyuh di seluruh Indonesia pada tahun 2015 mencapai 12.904.000 ekor dan mengalami kenaikan (1,11\%) dibandingkan tahun 2014 dengan jumlah populasi sebanyak 12.692.000 ekor. Peningkatan jumlah populasi puyuh diiringi dengan tingkat produksi telur sebesar 20,8 ribu ton pada tahun 2015 (Kementerian Pertanian, 2015). Puyuh dapat mencapai dewasa kelamin sekitar umur 42 hari dengan produksi telur antara 200-300 butir setiap tahun (Listiyowati dan Roospitasari, 2000) serta saat ini puyuh banyak diternakkan di Indonesia sehingga untuk dapat memenuhi kebutuhan masyarakat akan telur puyuh perlu dilakukan khususnya dengan peningkatan kualitas dan kuantitas pakan.

Peningkatan penampilan produksi ternak salah satunya adalah dengan mempertahankan kualitas dan kuantitas pakan dan penambahan feed additives dalam pakan. Bahan yang tidak termasuk zat makanan yang ditambahkan pada pakan dalam jumlah sedikit serta bertujuan memacu pertumbuhan dan meningkatkan efisiensi pakan disebut juga dengan feed additives dimana salah satu yang dapat digunakan dalam pakan 
unggas khususnya puyuh yaitu tepung pegagan.

Pegagan memiliki kandungan diantaranya asam amino, flavonoid, terpenoid, dan minyak atsiri. Terpenoid khususnya triterpenoid merupakan kandungan utama dalam pegagan, terdiri atas asiatikosida, madekasosida, brahmosida, dan brahminosida (glikosa saponin), asam asiaticentoic, asam centellic, asam centoic, dan asam madekasat dan vitamin khususnya vitamin C (Herlina et al., 2011). Daun pegagan merupakan salah satu pakan yang diduga dapat meningkatkan produktivitas puyuh karena kandungan flavonoidnya (Anfiandi, 2013). Hasil ini menunjukkan bahwa daun pegagan dapat digunakan sebagai bahan tambahan dalam pakan serta sebagai sumber antioksidan alami.

Penelitian tentang pemberian tepung daun pegagan pada pakan puyuh yang bertujuan untuk meningkatkan produktivitas puyuh yang sampai saat masih jarang dilakukan oleh karena itu tujuan dari penelitian ini adalah mengetahui penambahan tepung pegagan pada pakan puyuh sehingga diharapkan dengan pemberian tepung pegagan dalam pakan dapat meningkatkan produksi pada puyuh.

MATERI DAN METODE
Penelitian dilakukan di Laboratorium Program Studi Peternakan Fakultas Pertanian Universitas Tanjungpura pada bulan April sampai bulan Juli 2016. Materi yang digunakan adalah puyuh petelur sebanyak 200 ekor dimana setiap ekor puyuh diberikan pakan sebanyak $35 \mathrm{~g} / \mathrm{hari}$. Metode yang digunakan adalah percobaan dengan menggunakan Rancangan Acak Lengkap (RAL) dengan 4 perlakuan dan 5 ulangan dengan masing-masing ulangan menggunakan 10 ekor puyuh. Perlakuan dalam penelitian ini pakan puyuh tanpa penambahan tepung daun pegagan $\left(\mathrm{P}_{0}\right)$; $0,5 \% \quad\left(\mathrm{P}_{1}\right) ; 1 \% \quad\left(\mathrm{P}_{2}\right)$ dan $1,5 \% \quad\left(\mathrm{P}_{3}\right)$. Variabel pengamatan meliputi konsumsi pakan (g/ekor), produksi telur (\%), konversi pakan dan bobot telur (g). Data dianalisis dengan analisis ragam (ANOVA) jika ada perbedaan antar perlakuan dilanjutkan dengan Uji Duncan's. (Steel and Torie, 2003)

\section{HASIL DAN PEMBAHASAN}

Berdasarkan hasil penelitian diperoleh rataan konsumsi pakan, berat telur, konversi pakan dan produksi telur puyuh yang diberi penambahan tepung pegagan pada pakan, dimana data dapat dilihat pada Tabel 1.

Tabel 1. Rataan konsumsi pakan, berat telur, konversi pakan dan produksi telur puyuh yang diberi penambahan tepung pegagan pada pakan

\begin{tabular}{ccccc}
\hline Perlakuan & $\begin{array}{c}\text { Konsumsi } \\
\text { Pakan }(\mathbf{g})\end{array}$ & $\begin{array}{c}\text { Produksi Telur } \\
(\boldsymbol{\%})\end{array}$ & $\begin{array}{c}\text { Konversi } \\
\text { Pakan }\end{array}$ & Berat telur $(\mathbf{g})$ \\
\hline $\mathrm{P}_{0}$ & $25,42 \pm 0,18$ & $67,71 \pm 2,05$ & $2,61 \pm 0,13$ & $9,36 \pm 0,42$ \\
$\mathrm{P}_{1}$ & $25,61 \pm 0,24$ & $68,45 \pm 3,51$ & $2,65 \pm 0,14$ & $9,32 \pm 0,54$ \\
$\mathrm{P}_{2}$ & $25,45 \pm 1,27$ & $68,21 \pm 3,02$ & $2,62 \pm 0,21$ & $9,34 \pm 0,55$ \\
$\mathrm{P}_{3}$ & $25,82 \pm 0,87$ & $69,04 \pm 5,32$ & $2,64 \pm 0,31$ & $9,30 \pm 0,64$ \\
\hline
\end{tabular}

Ket: hasil analisa data menunjukkan tidak terdapat perbedaan nyata $\mathrm{P}>0.01$ 
Hasil analisis ragam menunjukkan bahwa penambahan tepung daun pegagan (Centella asiatica) pada pakan tidak berpengaruh $(\mathrm{P}>0,05)$ terhadap konsumsi pakan, konversi pakan, produksi telur dan berat telur puyuh. Rataan konsumsi pakan, konversi pakan, produksi telur dan berat telur pada puyuh yang diberi tambahan pakan dengan tepung pegagan dapat dilihat pada Tabel 1.

Jumlah pakan yang dimakan dalam jumlah waktu tertentu yang akan digunakan oleh ternak untuk memenuhi kebutuhan hidup disebut juga dengan konsumsi pakan (Wahju, 2004). Hasil pengamatan menunjukkan konsumsi pakan tertinggi terdapat pada perlakuan $\mathrm{P}_{3}$ sebesar 25,82 $\pm 0,87$ g/ekor/hari walaupun secara statistik tidak berpengaruh antar perlakuan. Tingginya konsumsi pakan pada perlakuan ini diduga karena kandungan serat kasar yang meningkat seiring dengan penambahan tepung pegagagan pada pakan dan perubahan warna pakan yang semakin hijau. Untuk pakan perlakuan $\mathrm{P}_{3}$ (1,5\% tepung daun pegagan) yang kandungan serat kasarnya lebih tinggi maka konsumsi pakannya lebih banyak selain itu konsumsi pakan pada puyuh dipengaruhi oleh warna pakan. Hal ini disebabkan karena semakin meningkatnya kandungan tepung daun pegagan dalam pakan maka pakan semakin berwarna hijau. Sesuai dengan pernyataan Sturkie (2000) yang menyatakan bahwa konsumsi pakan pada unggas lebih dipengaruhi oleh warna pakan dan ayam lebih menyukai pakan yang berwarna kuning, merah dan hijau. Hasil penelitian Wardiny (2006) menyebutkan bahwa ransum yang berwarna lebih hijau memiliki palabilitas yang lebih baik.

Produksi telur pada semua perlakuan berkisar $67-69 \%$. Hasil analisis ragam menujukkan bahwa produksi telur tidak dipengaruhi $(\mathrm{P}>0.05) \quad$ oleh perlakuan pakan. Produksi telur pada puyuh yang mendapat perlakuan penambahan tepung daun pegagan pada pakan cenderung mempunyai produksi meningkat dibandingkan dengan puyuh tanpa pemberian tepung daun pegagan dalam pakan. Hal ini disebabkan konsumsi pakan puyuh yang mendapat perlakuan penambahan tepung daun pegagan dalam pakan lebih tinggi dibandingkan dengan pakan perlakuan lainnya, selain itu jika dilihat bahwa pada daun pegagan mengandung $\mathrm{Na}, \mathrm{Fe}$, Vitamin A dan $\mathrm{C}$ yang berperan dalam pertumbuhan sehingga dapat meningkatkan produksi telur karena puyuh menjadi lebih cepat dewasa kelamin atau bertelur, sehingga telur yang dihasilkan lebih banyak. Lebih jelasnya dapat dilihat jumlah produksi telur yang dihasilkan pada Tabel 1.

Nutrisi pada pakan yang ditambah tepung daun pegagan akan semakin meningkat seperti protein, vitamin dan mineral dimana komponen tersebut tersedia dalam jumlah cukup dibandingkan dengan pakan perlakuan lainnya. Selain itu daun pegagan mengandung flavonoid dapat meningkatkan produksi telur. Penelitian Palupi et al. (2014) melaporkan pemberian suplemen flavonoid yang berasal tepung Indigfera zollingeriana dapat menghasilkan produksi telur harian lebih tinggi jika dibandingkan perlakuan 
kontrol karena tepung Indigofera zollingeriana mengandung $\beta$-karoten, $\alpha$ tokoferol dan flavonoid sebagai antioksidan alami berperan sebagai pereda stres panas. Rosa et al (2011) menambahkan suhu dan kelembaban dapat menyebabkan stres sehingga akan mempengaruhi kinerja dan produktifitas puyuh yang berkaitan dengan berkurangnya pembentukan vitamin C akibat gangguan pada organ tubuh penghasil vitamin $\mathrm{C}$ tersebut sehingga untuk memenuhi kebutuhannya perlu ditambahkan dari luar. Pemberian antioksidan yang mengandung flavonoid dan vitamin $\mathrm{C}$ pada pakan dapat meningkatkan imunitas humoral pada unggas yang diberi cekaman panas (Angwanich et al., 2003).

Konversi pakan merupakan salah satu indikator keberhasilan usaha bagi perternak. Konversi pakan untuk produksi telur merupakan perbandingan antara jumlah pakan yang dikonsumsi (g) dengan produksi telur (butir) yang dihasilkan. Hasil analisis ragam menunjukkan pemberian tepung daun pegagan pada pakan tidak berpengaruh $(\mathrm{P}>0,05)$ terhadap konversi pakan pada puyuh. Konversi pakan tertinggi terdapat pada perlakuan $\mathrm{P}_{3}$ sebesar 2,62 $\pm 0,31$ sedangkan terendah di perlakuan $\mathrm{P}_{0}$ sebesar 2,68 $\pm 0,13$. Hasil ini diperkuat oleh penelitian Nastiti dkk (2014) yang melaporkan bahwa penambahan tepung mengkudu dapat meningkatkan konversi pakan puyuh dimana konversi pakan yang terbaik dihasilkan oleh $\mathrm{P}_{0}$ sebesar $2,61 \pm 0,13$ walaupun secara statistik tidak berpengaruh nyata.
Ukuran telur dapat diartikan sebagai besar kecilnya telur yang dinyatakan dalam bobot. Yuwanta (2010) menyatakan bahwa berat telur puyuh adalah antara 8-10 g. Berat kuning telur puyuh adalah 2,4-3,3 g, putih telur 4,16-6 g, dan kerabang telur 0,56-0,9 g/butir telur. Hasil analisis ragam menujukkan perlakuan tidak berpengaruh $(\mathrm{P}>0.05)$ terhadap berat telur tetapi secara rataan beratnya menurun seiring bertambahnya tepung daun pegagan yang ditambahkan pada pakan. Puyuh yang mendapat pakan dengan perlakuan penambahan tepung daun pegagan lebih rendah berat telurnya dibandingkan dengan puyuh tanpa perlakuan. Nilai rata-rata bobot telur dari semua perlakuan adalah 9,30-9,36 g/butir dan nilai rataan ini masih dikatakan normal pada telur puyuh. Rendahnya berat telur ini dikarenakan semakin banyak penambahan tepung pegagan pada pakan maka akan semakin tinggi kandungan serat kasar dalam pakan. Tingginya serat kasar dalam pakan akan menyebabkan penyerapan nutrien tidak dapat maksimal karena serat kasar dalam pakan akan tinggal di saluran pencernaan dalam waktu yang singkat sehingga terjadi penuruanan absorbsi zat makanan yang dapat berpengaruh terhadap produksi dan berat telur pada puyuh (Piliang dan Djojosoebagio 2006).

\section{KESIMPULAN}

Berdasarkan hasil penelitian dapat disimpulkan bahwa pemberian tepung pegagan dapat meningkatkan produksi dan berat telur serta menurunkan konsumsi dan konversi pakan pada puyuh. Penambahan tepung pegagan 
dalam pakan sebesar 1,5\% memberikan efek terbaik terhadap performa puyuh.

\section{DAFTAR PUSTAKA}

Aengwanich, W., P. Sridama., Y. Phasuk, T. Vongpralab., P. Pakdee., S. Katawatin and S. Simaraks., (2003). Effects of ascorbic acid on cell mediated, humoral immune response and pathophysiology of white blood cell in broilers under heat stress, J. Sci. Technol. 25:297-305

Anfiandi, V. (2013). Uji teratogenik infusa daun pegagan (Centella asiatica (L.) Urban) pada mencit betina (Mus musculus). Calyptra. 2(1):1-15

Herlina, Kamaluddin, M, T, dan Hutasoit, L (2011). Pengaruh senyawa murni dari pegagan (Centella asiatica (L.) Urban) terhadap fungsi kognitif belajar dan . mengingat dan efek toksisitas pada mencit (Mus musculus) betina. Prosiding Seminar Nasional Sains IV, IPB, Bogor, pp. 138

Kementerian Pertanian. (2015). Statistik Peternakan dan Kesehatan Hewan 2015. Direktorat Jenderal Peternakan dan Kesehatan Hewan. Kementerian Pertanian RI. Jakarta.

Listiyowati E. dan K. Roospitasari. (2000). Tata Laksana Budi Daya
Burung Puyuh Secara Komersial. Penebar Swadaya. Jakarta

Palupi, R., L. Abdullah., D.A. Astuti and Sumiati.,(2014). Potential and utilization of Indigofera sp. shoot leaf meal as soybean meal substitution in laying hen diets. JITV. 19(3):210-219.

Piliang, W.G. dan S.A.H. Djojosoebagio., (2006). Fisiologi Nutrisi Vol I. Pusat Antar Universitas Ilmu Hayati. Institut Pertanian Bogor. Bogor

Rosa, G.A., L.A. Sorbello., R.L. Dittrich., M.T.T. Moraes and E.G. Oliveira., (2011). Blood profile of japanese quail (Coturnix japonica) under thermal stress. Ciencia Rural, Santa Maria. 41(9):1605-1610

Sturkie, P. D. (2000). Avian Physiology. 4th Edition. Springer-Verlag, New York.

Wahju, J. (2004). Ilmu Nutrisi Unggas. Universitas Gadjah Mada Press, Yogyakarta

Wardiny, T. M. (2006) Kandungan vitamin A,C dan kolesterol telur ayam yang diberi mengkudu (Morinda citrifolia) dalam ransum. Tesis. Institut Pertanian Bogor. Bogor.

Yuwanta, T. (2010). Telur dan Kualitas Telur. Gadjah Mada University Press. Yogyakarta 